SECTION 31. Economic research, finance, innovation.

Inna Aleksandrovna Akhnovskaya Ph.D. professor of the Department "Economy of Enterprise"

National University of Donetsk, Ukraine akhnovskaya@yandex.ru

Olga Vladimirovna Glushich Student of the Department "Economy of Enterprise" National University of Donetsk, Ukraine glushicholga88@mail.ru

\title{
ORGANIC FARMING AS THE KEY FOR EUROPEAN RURAL DEVELOPMENT
}

Abstract: This article presents opportunities, that provided by organic farming, as the branch of the European economy. Basically in direction of the rural development, that nowadays is in depressive situation.

Key words: organic farming, rural development, supply chain, environment, economy, workplace, market.

\section{ОРГАНИЧЕСКОЕ СЕЛЬСКОЕ ХОЗЯЙСТВО- КЛЮЧ К РАЗВИТИЮ СЕЛЬСКИХ РАЙОНОВ ЕВРОПЫ}

Аннотация: В данной статье представлены возможности относительно новой для Европейского хозяйствования отрасли, а именно органического сельского хозяйства. В особенности в направлении частичной рурализации, как субъекта развития сельских районов, находящихся в депрессивном состоянии.

Ключевые слова: органическое сельское хозяйство, развитие сельских районов, иепочки поставок, окружающая среда, экономика, рабочие места, рынок.

Organic farming becomes the part of our lives today. Every European Union citizen or somebody, who have lived in the EU during the past few years, no doubt come into contact with some aspect of organic food or farming and its associated supply chain.

The word "organic" is everywhere on a fruits and vegetables in supermarkets, or perhaps alongside a menu description of steak in a restaurant. Also, it's possible to notice the EU organic farming logo, or a similar logo used in different countries, on the bottles of fruit juice or the cartons of eggs.

Organic farming is an agricultural system that seeks to provide to the consumer fresh, tasty and authentic food while respecting natural life-cycle systems. To achieve this, organic farming relies on a number of objectives and principles, as well as common practices designed to minimize the human impact on the environment, while ensuring the agricultural system operates as naturally as possible. In spite of this, organic farming is also part of a larger supply chain, which encompasses food processing, distribution and retailing sectors and, ultimately, consumer[1].

Increasing consumer demand for organic food has created many opportunities for all parts of the food supply chain, which has contributed to a corresponding increase in the economic and social development of many rural areas of the EU. Annual market growth for organic products is between $10-15 \%$. What can't be said about the most of others European economic markets [8]. 
As well as providing more financial security for organic farmers, processors, distributors and retailers, the economic benefits of this trend will inevitably trickle down to other rural businesses and the wider rural community - both directly and indirectly.

The very nature of organic farming means that it contributes to creating job opportunities, large rural populations and rural wealth. Factors contributing to this include:

$\circ$ organic farms tend to be smaller and more diversified than non-organic farms, which by comparison tend on the whole to be larger and more intensive managed;

$\circ$ the often high labour intensiveness created by restrictions on inputs and emphasis on physical and mechanical production;

○ high compatibility of organic farms to rural and eco-tourism ventures;

- new areas of research (plant protection, animal welfare, renewable resources) for scientists.

Also, organic farming provide very good working conditions. Organic farmers are more likely to experience health benefits from not having to work with chemicals such as pesticides. And their workplace is eco-friendly as well as their production [7].

Organic farmers also report gaining the respect of consumers as more and more people find out about the environmental, animal welfare and socio-economic benefits of organic production.

Even the fact, that organic farming creates more attractive natural landscapes is economy-friendly. As known the rural populations are dwindling throughout the EU. People trying to move to the big cities, searching for job and good life. Organic farming not only provides new working places. But also increases the overall attractiveness of rural areas, making them more likely to lure and retain inhabitants. Through its focus on planting hedges and meadows, retaining native flora and fauna, protecting and enhancing water and soil resources, using native plant and animal species and resources.

Organic farming can also contribute to the greater involvement of rural communities in the food supply chain. This is due to the use of varied market channels - for example, farm gate sales, farm shops and farmers' markets and internet-based delivery schemes, also to new and varied marketing opportunities, and to the preference for shorter transportation distances to market.

In fact, members of the organic supply chain are often actively involved in more than one of these links. Farmers take great pride and emotional interest in their organic products and often participate in their processing and marketing side of things as well.

This often means that farmers can speak directly to consumers about the products that they are buying, helping them to understand exactly how the food has been produced and the wide-ranging benefits of a more sustainable approach to food production. In this manner, they raise awareness among consumers and advise them on the implications of the food and drink they consume. So this even stimulates growing of the consumer demand, and, as the result, job opportunities becoming greater. The more people buying organic, the more challenging and exciting jobs can be found throughout the organic farming supply chain [4].

The most obvious opportunities exist on the farm, where the more traditional hands-on approach to agriculture creates a need for a large number of workers of all levels of experience.

Organic farmers often take on large numbers of apprentices and trainees to ensure the next generation of farmers adopt a more sustainable mix of traditional and modern scientific agricultural practices. The possibility to work on smaller, more diversified holdings in the organic farming sector also increases the opportunities for newcomers to agriculture, particularly at a time when the average age of farmers is well over 60 and fewer and fewer people are choosing to enter the agricultural sector. 
Organic Works, a 2006 survey from the UK's Soil Association, found organic farming in the UK provides $32 \%$ more jobs per farm than equivalent non-organic farms, while organic farmers in the UK were on average seven years younger than non-organic farmers $[5,64]$.

The healthy image of nature and agriculture fostered by organic farming provides opportunities to establish rural and eco-tourism ventures, demonstration farms, open days and other accommodation and hospitality ventures.

Hospitality, marketing and tourism professionals are among the types of employees who can benefit from this trend.

Animal welfare is also a space for searching job. Due to organic farming's emphasis on maintaining high standards of animal health and welfare, people working with organic animals must be committed and highly skilled. These qualities extend not only to farmers and farm labourers but also to veterinarians and veterinary medicine suppliers, animal feed suppliers and other service providers, such as livestock housing specialists [3].

But not only farm labourers can find their place. This area also need more researches.

The different needs of organic farming - such as the need for information and research on controlling weeds without herbicides or producing high yields without reliance on synthetic fertilisers - also create more opportunities in the many different fields of related scientific research, including cropping systems, plant protection, plant nutrition, animal health and welfare, animal nutrition.

The wide variety of market channels used by organic farmers and processors create a similarly wide number of new retail positions and opportunities in the related processing and distribution sectors.

Organic farming also needs transport operators who can meet the specific demands of the industry, namely the delivery of products to markets within short distances and a short amount of time, effective separation of organic and non-organic produce at all times, minimisation of transport times and any associated stress and suffering of livestock.

Of course rural development it is not only work places. It's one of the most important parts that help increase economy level of all European countries, but not the one.

European Union is supporting the development of rural areas, environment protection and conservation and maintaining landscape capacities. From 2002 the official channel of this support is the SAPARD frame program where one of the target activities

is organic farming in a wider context, that means production, processing and marketing. Eco-tourism is also supported which serves for the environment in different aspects:

1. Recreation in rural environment: contributes to development of rural infrastructure, improves the population keeping ability of the area and offers work places.

2. Offering organic foods: Producer offers and sells locally grown organic foods for the guest.

3. Fairs, exhibitions, local eco-markets: Displaying, offering and selling eco-products by regional or micro regional producers. number of

4. Organising programs: traditional pig slaughting or a simple animal fair can attract a

visitors.

5. (Re)Forming architecture style: traditional building materials and styles that reflect a certain nature based sense.

6. Innovation, offering high quality services: targeting on conscious and self defining market segments.

In West-European countries a well proved method is to open up eco-restaurants and hotels, where the foods and dishes are prepared from controlled organic materials but even the architectural issues reflect the closeness to nature. 
If this trend will continue his development, Europe could finally got rural development, which was impossible for so many years.

\section{References:}

1. Buckwell A. (1997). Towards a Common Agricultural and Schumacher, E.E. 1979. Small is Beautiful: A Study of Economics as if People Mattered. London: Abacus.

2. Csaki C., Tuck L., Rural Development Strategy: Eastern Europe and Central Asia 2000, p. 64

3. Dabbert S., Häring A.M., Zanoli R., Organic Farming: Policies and Prospects 2013, p 190.

4. Groot, J. C. J., Rossing, W. A. H. \& Lantinga, E. A. (2006a) Evolution of Farm Management, Nitrogen Efficiency and Economic Performance of Dairy Farms Reducing External Inputs, Livestock Production Science, 100.

5. Ploeg, J. D. van der (2006) Agricultural production in crisis, in: T. Marsden, P. Cloke \& P. H. Mooney (Eds) Handbook of Rural Studies, p. 277 (London: Sage).

6. [Электронный ресурс] http://www.soilassociation.org - Soil Association. Organic works. 2006/ (Дата доступа 13.03.2014).

7. [Электронный ресурс] http://www.soilassociation.org/LinkClick.aspx?fileticket=60CVIT1Nw0U\%3D\&tabid $=387$ Rural Policy for Europe. In: European Economy, European Commission Directorate ñ General for Economic and Financial Affairs, Reports and Studies, No 5, Luxembourg, pp 15-22 (Дата доступа 13.03.2014).

8. [Электронный ресурc] http://www.ifoam.org/- International Federation of Organic Agriculture Movements (IFOAM) (Дата доступа 13.03.2014).

9. http://www.jandouwevanderploeg.com/ Rural Development: challenges and interlinkages

10. http://theorganicsinstitute.com/about-us/the-organics-institute/ The Organics Institute 